\title{
Relationship between Dietary Fiber Fermentation and Volatile Fatty Acids' Concentration in Growing Pigs
}

\author{
Jinbiao Zhao, Yu Bai, Gang Zhang, Ling Liu and Changhua Lai * \\ State Key Laboratory of Animal Nutrition, Ministry of Agriculture and Rural Affairs Feed Industry Centre, \\ China Agricultural University, Beijing 100193, China; 15600911358@163.com (J.Z.); yubaijlucau@163.com (Y.B.); \\ 18729564631@163.com (G.Z.); $18435132241 @ 163 . c o m$ (L.L.) \\ * Correspondence: laichanghua999@163.com; Tel.: +86-10-6273-1109
}

Received: 14 November 2019; Accepted: 1 February 2020; Published: 7 February 2020

Simple Summary: The study suggests differences in fermentable capacity of fibrous feed ingredients are associated with fiber composition in pig. Results demonstrate that the fiber digestibility of oat bran, sugar beet pulp and soybean hulls is greater than for corn bran, wheat bran and rice bran in the pig intestine. Furthermore, results indicate that volatile fatty acids' concentration (VFA) is positively correlated primarily with insoluble dietary fiber (IDF) fermentation, and the digestibility of IDF is the best single variable to predict fecal VFA concentrations. The contribution of this study is to provide instructions on how to implement fiber-rich ingredients effectively in the feed formulation for swine.

\begin{abstract}
This study was conducted to determine whether differences in fiber fermentation in fiber-rich feed ingredients exist and to assess relationship between fiber fermentation and concentration of volatile fatty acids (VFA) in pig. Castrated males (barrows) were allotted randomly to six diets formulated with different amounts of wheat bran (WB), corn bran (CB), sugar beet pulp (SBP), oat bran (OB), soybean hulls (SH) or rice bran (RB). The apparent ileal digestibility (AID) of soluble dietary fiber (SDF) for $\mathrm{OB}$ and $\mathrm{SH}$ diets was greater $(P<0.05)$ than for the other diets. The fermentation of total dietary fiber (TDF) and insoluble dietary fiber (IDF) in the hindgut were greater $(P<0.05)$ for $\mathrm{SBP}$ and $\mathrm{SH}$ diets than for $\mathrm{WB}, \mathrm{CB}, \mathrm{OB}$ and $\mathrm{RB}$ diets. The apparent total tract digestibility (ATTD) values of all fiber components in SBP, SH and $\mathrm{OB}$ diets were greater $(P<0.05)$ than for $\mathrm{WB}, \mathrm{CB}$ and $\mathrm{RB}$ diets. The concentration of VFA in feces was positively correlated with the ATTD of IDF and cellulose, and ATTD of IDF is the best factor for predicting fecal VFA concentration. Overall, dietary fiber source affected fermentable characteristics of fiber components in the different digestive segments of pig intestine.
\end{abstract}

Keywords: correlation; digestibility; dietary fiber; pig; short chain fatty acid

\section{Introduction}

Dietary fiber is resistant to digestion by endogenous enzymes in the small intestines of pigs, but can be partially or completely fermented by microbiota in the hindgut to produce volatile fatty acids (VFA) that are absorbed to provide energy [1]. The production of VFA by fiber fermentation plays an important role in regulating host metabolism, immune system and cell proliferation $[2,3]$. It can not only bind to the G protein-coupled receptors (GPRs) that are expressed on both intestinal epithelia and immune cells [4], but also modulates satiety and gut motility via activation of GPR43 on enteroendocrine L-cells to stimulate the release of the anorectic gut hormones, such as glucagon-like peptide-1 and peptide YY [5]. Dietary fiber is mainly composed of soluble dietary fiber (SDF) and insoluble dietary fiber (IDF), and SDF is easier to ferment by gut bacteria compared to IDF $[6,7]$. Soluble fibers include pectin, gum, $\beta$-glucan and hemicellulose, whereas cellulose consists of insoluble 
fibers [8]. Traditionally, dietary fiber is thought to be fermented in the hindgut of the pig, but recent studies reported that it is also fermented in the small intestine, since fiber-degrading bacteria are found in the upper gut of the pig $[9,10]$. However, there is large amount of variation in the fermentation potential of fiber components from highly fermentable pectin to cellulose that is slowly fermentable. Thus, considerations of fiber fractions fermentation in feedstuffs and estimating their nutritional values are critically important for the swine industry.

In our previous study, we reported that sources of dietary fiber, derived from wheat bran (WB), corn bran (CB), sugar beet pulp (SBP), oat bran (OB), soybean hulls (SH) and rice bran (RB), affected VFA production and composition of gut microbiota in the intestine of the pig due to their differences in chemical composition and physical properties, and VFA produced by gut microbiota to ferment dietary fiber is positively correlated to IDF content in fiber-rich ingredients, not SDF [11]. However, the relationship between VFA production and fermentable capacity of various fiber components is not known, and no previous studies have been focused on the development of predictive equations for VFA concentration. Based on our previous study, we put forward the hypothesis that different sources of dietary fiber among fibrous feed ingredients vary in degree of fermentation in the different segments of the digestive tract of pigs, and VFA production is positively correlated to the fermentable capacity of insoluble fibers.

Therefore, the objectives of this study were to determine the effects of dietary fiber sources from feed ingredients with equally total dietary fiber (TDF) content on nutrient digestibility and fiber fermentation in different segments of the intestinal tracts of pigs and to determine the relationship between the fermentation of different dietary fiber components and concentration of VFA in the ileal digesta and feces of the pig.

\section{Materials and Methods}

The Laboratory Animal Welfare and Animal Experimental Ethical Inspection Committee in China Agricultural University reviewed and approved all protocols used in this study (number AW12119102-2-1). The animal trial was conducted at the Swine Research Unit of China Agricultural University (Beijing, China).

\subsection{Animals and Housing}

Thirty-six Duroc $\times($ Landrace $\times$ Yorkshire) crossbred barrows (initial body weight of $48.5 \pm 2.1 \mathrm{~kg}$ ) were fitted surgically with a T-cannula in the distal ileum, as described by Stein et al. [12]. Pigs were allowed a 15-day recovery period after surgery, and a corn-soybean meal diet was fed during this period. The composition of ingredients and the analyzed nutritive levels in the corn-soybean meal diet are presented in Supplementary Table S1. All pigs were housed in individual stainless-steel metabolism crates $(1.4 \times 0.7 \times 0.6 \mathrm{~m})$ equipped with nipple drinking devices and feed boxes. The room temperature was maintained at $20-25{ }^{\circ} \mathrm{C}$ throughout the experiment.

\subsection{Experimental Design and Diets}

The pigs were allotted randomly to 6 dietary treatments, for a total of 6 pigs per treatment. The different dietary treatments were formulated with either $\mathrm{WB}, \mathrm{CB}, \mathrm{SBP}, \mathrm{OB}, \mathrm{SH}$ or $\mathrm{RB}$ as the sole dietary fiber source for each dietary treatment. The chemical compositions of $\mathrm{WB}, \mathrm{CB}, \mathrm{SBP}, \mathrm{OB}, \mathrm{SH}$ and RB were analyzed. All high-fiber diets were formulated to contain the same level (15\%) of TDF by adjusting the inclusion level of $\mathrm{WB}, \mathrm{CB}, \mathrm{SBP}, \mathrm{OB}, \mathrm{SH}$ and $\mathrm{RB}$ in each diet. The feed ingredients and chemical compositions of diets were analyzed, and results are summarized in Table 1. Vitamins and minerals were included in all diets to meet or exceed the nutrient requirements for growing pigs [13]. All diets contained $0.3 \%$ chromic oxide as an indigestible marker. The experiment lasted $21 \mathrm{~d}$, including $15 \mathrm{~d}$ for diet adaptation, $3 \mathrm{~d}$ for fecal collection and $3 \mathrm{~d}$ for digesta collection. 
Table 1. The composition of experimental diets ${ }^{1}$.

\begin{tabular}{|c|c|c|c|c|c|c|}
\hline \multirow[b]{2}{*}{ Items } & \multicolumn{6}{|c|}{ Diets } \\
\hline & WB & CB & SBP & OB & SH & RB \\
\hline \multicolumn{7}{|l|}{ Ingredients, $\mathrm{g} / \mathrm{kg}$} \\
\hline Corn starch & 350.8 & 453.6 & 459.5 & 346.3 & 451.3 & 214.3 \\
\hline Soy protein isolate & 120.0 & 120.0 & 140.0 & 120.0 & 140.0 & 110.0 \\
\hline RB & - & - & - & - & - & 500.0 \\
\hline WB & 357.0 & - & - & - & - & - \\
\hline $\mathrm{CB}$ & - & 250.0 & - & - & - & - \\
\hline SBP & - & - & 225.0 & - & - & - \\
\hline OB & - & - & - & 358.0 & - & - \\
\hline $\mathrm{SH}$ & - & - & - & - & 235.0 & - \\
\hline Soy oil & 30.0 & 30.0 & 30.0 & 30.0 & 30.0 & 30.0 \\
\hline Sucrose & 100.0 & 100.0 & 100.0 & 100.0 & 100.0 & 100.0 \\
\hline Limestone & 11.0 & 5.5 & - & 5.0 & - & 5.0 \\
\hline Dicalcium phosphate & 8.0 & 6.0 & 22.0 & 18.0 & 21.0 & 18.0 \\
\hline L-Lysine-HCl & 4.0 & 4.8 & 3.5 & 4.2 & 3.0 & 3.2 \\
\hline DL-Methionine & 1.2 & 1.6 & 1.5 & - & 1.2 & 1.2 \\
\hline L-Threonine & 1.5 & 2.0 & 2.0 & 2.0 & 2.0 & 1.8 \\
\hline $\mathrm{Cr}_{2} \mathrm{O}_{3}$ & 3.0 & 3.0 & 3.0 & 3.0 & 3.0 & 3.0 \\
\hline $\mathrm{NaCl}$ & 4.5 & 4.5 & 4.5 & 4.5 & 4.5 & 4.5 \\
\hline $\mathrm{K}_{2} \mathrm{CO}_{3}$ & 3.0 & 3.0 & 3.0 & 3.0 & 3.0 & 3.0 \\
\hline $\mathrm{MgO}$ & 1.0 & 1.0 & 1.0 & 1.0 & 1.0 & 1.0 \\
\hline Premix $^{2}$ & 5.0 & 5.0 & 5.0 & 5.0 & 5.0 & 50 \\
\hline \multicolumn{7}{|c|}{ Chemical analyses, $\mathrm{g} / \mathrm{kg}$ DM basis } \\
\hline $\mathrm{GE}, \mathrm{MJ} / \mathrm{kg}$ & 18.23 & 18.47 & 18.18 & 17.99 & 18.30 & 18.06 \\
\hline $\mathrm{CP}$ & 127.5 & 133.2 & 137.6 & 142.8 & 133.3 & 152.2 \\
\hline Ash & 44.2 & 43.0 & 49.0 & 60.0 & 48.6 & 85.2 \\
\hline $\mathrm{OM}$ & 955.8 & 957.0 & 951.0 & 940.0 & 951.4 & 914.8 \\
\hline $\mathrm{EE}$ & 22.4 & 18.3 & 7.3 & 58.0 & 15.9 & 15.7 \\
\hline TDF & 164.1 & 171.3 & 165.8 & 165.4 & 174.2 & 163.2 \\
\hline SDF & 14.4 & 7.7 & 65.4 & 75.0 & 32.9 & 14.5 \\
\hline IDF & 149.7 & 163.6 & 100.4 & 90.4 & 141.3 & 148.7 \\
\hline NDF & 140.7 & 179.3 & 136.1 & 179.6 & 181.1 & 150.6 \\
\hline $\mathrm{ADF}$ & 38.7 & 46.4 & 59.7 & 31.5 & 108.0 & 59.6 \\
\hline Cellulose & 30.6 & 39.2 & 43.2 & 20.0 & 92.9 & 10.3 \\
\hline Hemicellulose & 102.0 & 132.9 & 76.4 & 148.1 & 73.1 & 90.9 \\
\hline \multicolumn{7}{|c|}{$\begin{array}{l}{ }^{1} \mathrm{ADF}=\text { acid detergent fiber; } \mathrm{ADL}=\text { acid detergent lignin; } \mathrm{CB}=\text { corn bran; } \mathrm{CP}=\text { crude protein; } \mathrm{DM}=\text { dry matter } \\
\mathrm{EE}=\text { ether extract; } \mathrm{IDF}=\text { insoluble dietary fiber; } \mathrm{NDF}=\text { neutral detergent fiber; } \mathrm{OB}=\text { oat bran; } \mathrm{OM}=\text { organic matter } \\
\mathrm{RB}=\text { rice bran; } \mathrm{SDF}=\text { soluble dietary fiber; } \mathrm{SBP}=\text { sugar beet pulp; } \mathrm{SH}=\text { soybean hulls; } \mathrm{TDF}=\text { total dietary fiber } \\
\mathrm{WB}=\text { wheat bran. }{ }^{2} \text { Premix provided the following quantities per kilogram of the complete feed for growing pigs } \\
\text { vitamin } \mathrm{A}, 5512 \mathrm{IU} \text {; vitamin } \mathrm{D}_{3}, 2200 \mathrm{IU} \text {; vitamin } \mathrm{E}, 64 \mathrm{IU} \text {; vitamin } \mathrm{K}_{3}, 2.2 \mathrm{mg} \text {; vitamin } \mathrm{B}_{12}, 27.6 \text { ug; riboflavin } \\
5.5 \mathrm{mg} \text {; pantothenic acid, } 13.8 \mathrm{mg} \text {; niacin, } 30.3 \mathrm{mg} \text {; choline chloride, } 551 \mathrm{mg} ; \mathrm{Mn}(\mathrm{MnO}), 40 \mathrm{mg} ; \mathrm{Fe}\left(\mathrm{FeSO}_{4} \cdot \mathrm{H}_{2} \mathrm{O}\right) \\
100 \mathrm{mg} \text {; } \mathrm{Zn}(\mathrm{ZnO}), 100 \mathrm{mg} ; \mathrm{Cu}\left(\mathrm{CuSO}_{4} \cdot 5 \mathrm{H}_{2} \mathrm{O}\right), 100 \mathrm{mg} \text { I }(\mathrm{KI}), 0.3 \mathrm{mg} ; \mathrm{Se}\left(\mathrm{Na}_{2} \mathrm{SeO}_{3}\right), 0.3 \mathrm{mg} \text {. }\end{array}$} \\
\hline
\end{tabular}

Pigs were provided water ad libitum and fed a daily amount of feed equivalent to $4 \%$ of body weight divided equally into two meals provided at 08:00 and 16:00. Body weights of individual pigs were recorded at the beginning of the experiment to calculate the feed allowance.

\subsection{Sample Collection}

Fecal samples were collected from 08:00 to 18:00 from day 16 to day 18 of the experiment via grab-sampling. The pallet was placed at the bottom of each cage to prevent contamination of fecal samples. During the $3 \mathrm{~d}$ collection period, feces were immediately collected into plastic bags and stored at $-20{ }^{\circ} \mathrm{C}$. Digesta samples were collected from day 19 to day 21 of the experiment at 08:00 and the last sample was obtained at 18:00 on each collection day. For digesta collection, a plastic bag was attached to the barrel of the cannula using a cable tie. Bags were removed when filled and stored at 
$-20{ }^{\circ} \mathrm{C}$ to prevent bacterial degradation of the samples. At the end of this animal trial, digesta and fecal samples from the same pig were thawed and mixed. Sub-samples of digesta (about $300 \mathrm{~g}$ ) and feces (about $200 \mathrm{~g}$ ) were lyophilized and then ground through a $1 \mathrm{~mm}$ screen. All sub-samples of ileal digesta and feces were stored at $-20^{\circ} \mathrm{C}$ prior to chemical analysis.

\subsection{Chemical Analyses}

The dry matter (DM) (Method 934.01), starch (Method 979.10), crude protein (Method 990.03), ether extract (EE) (Method 920.39), chromium (Method 990.08), ash (Method 942.05), SDF and IDF (Method 991.43; Ankom TDF Analyzer) were analyzed according to the procedures of the Association of Official Analytical Chemists [14]. Organic matter (OM) was calculated by difference between DM and ash. Total dietary fiber (TDF) was calculated as the sum of SDF and IDF. Neutral detergent fiber (NDF) and acid detergent fiber (ADF) were determined using fiber bags (Model F57, Ankom Technology, Macedon, NY, USA) and a fiber analyzer (ANKOM ${ }^{200}$ Fiber Analyzer, Ankom Technology, Macedon, NY, USA) after adaptation of the procedure described by Van Soest et al. [15]. The concentration of aNDF was analyzed using heat stable $\alpha$-amylase and sodium sulphite without correction for insoluble ash. The content of acid detergent lignin (ADL) was also determined according to the method of Ankom Technology. Hemicellulose was calculated as the difference between aNDF and ADF, and cellulose was calculated as the difference between ADF and ADL. Non-starch polysaccharide (NSP) was the difference as TDF and ADL. All samples of ingredients and diets were analyzed for water binding capacity [16]. Values for water binding capacity were expressed as the amount of water retained by the pellet $(\mathrm{g} / \mathrm{g}$ ). The gross energy (GE) of feces, diets and ingredients were determined using an Automatic Isoperibol Oxygen Bomb Calorimeter (Parr 1281 Calorimeter, Moline, IL, USA). The analysis and concentration of VFA in the ileal digesta and feces were cited from our previous publication [11]. About $1.0 \mathrm{~g}$ samples of ileal digesta and feces were put into $10 \mathrm{~mL}$ centrifuge tubes with $2.0 \mathrm{~mL} 0.10 \%$ hydrochloric acid, and incubated on ice for $25 \mathrm{~min}$. The tubes were mixed and centrifuged at 15,000 rpm for $15 \mathrm{~min}$. The supernatant was filtered using a $0.20 \mathrm{~mm}$ Nylon Membrane Filter (Millipore, Bedford, OH, USA) and poured into a Gas Chromatograph System (Agilent HP 6890 Series, Santa Clara, CA, USA) for VFA determination.

\subsection{Calculations}

The apparent ileal (AID) and total tract digestibility (ATTD) of DM, OM, GE, EE, ADF, NDF, cellulose, hemicellulose, TDF, SDF and IDF in ileal digesta or feces were calculated for all diets [17].

$$
\mathrm{AD}=1-\left(\mathrm{CN}_{\text {digesta or feces }} / \mathrm{CN}_{\text {diet }}\right) \times\left(\mathrm{Cr}_{\text {diet }} / \mathrm{Cr}_{\text {digesta or feces }}\right) .
$$

In this equation, $\mathrm{AD}$ is the $\mathrm{AID}$ or ATTD of energy or nutrients and fiber components fermentation of ileal digesta or feces in a diet (\%); $\mathrm{CN}_{\text {digesta or feces }}$ is the energy and nutritive level of ileal digesta or feces; $\mathrm{CN}_{\text {diet }}$ is the energy and nutritive level of a diet.

The digestible energy (DE, MJ/kg) in ileal digesta and feces of pigs was calculated according to the following equation:

$$
\mathrm{DE}=\mathrm{GE}_{\text {diet }} \times \mathrm{AD}_{\text {energy }}
$$

where $\mathrm{GE}_{\text {diet }}$ is GE content in each diet, and $\mathrm{AD}_{\text {energy }}$ is the AID or ATTD of GE in each diet.

The disappearance (\%) of DM, GE, EE, ADF, NDF, OM cellulose, hemicellulose, TDF, SDF and IDF and the content of DE $(\mathrm{MJ} / \mathrm{kg})$ in the hindgut were calculated according to the following equation:

$$
\begin{gathered}
\text { Hindgut disappearance }=\mathrm{ATTD}-\mathrm{AID} \\
\mathrm{DE}_{\text {hindgut }}=\mathrm{GE}_{\text {diet }} \times \mathrm{ATTD}_{\text {energy }}-\mathrm{GE}_{\text {diet }} \times \mathrm{AID}_{\text {energy }}
\end{gathered}
$$




\subsection{Statistical Analysis}

All the data were checked for normality and outliers were detected using the UNIVARIATE procedure of SAS (SAS Inst. Inc., Cary, NC, USA). No outliers were found. All data were analyzed using the MIXED procedure of SAS 9.2 with individual pig as the experimental unit. The statistical model included the fixed effect of diet and the random effects of individuals pig. Statistical differences among the treatments were separated by Tukey's multiple range test. Treatment means were calculated using the LSMEANS statement. Difference was considered significant at $P<0.05$. Pearson' s coefficient correlations between dietary fiber digestibility in the ileum and feces of the pig and VFA concentration were analyzed using the PROC CORR procedure of SAS 9.2. Prediction equations for acetate, propionate, butyrate and total VFA concentrations in the feces of pigs fed 6 dietary treatments were developed using PROC REG of SAS. Stepwise regression was used to determine effects of ATTD of different fiber components on fecal VFA concentrations. Variables with $P<0.10$ were retained in the model and the $\mathrm{R}^{2}$ values were used to define the best-fit models.

\section{Results}

There was no residual feed left by any pig during the entire experiment. All the pigs were healthy with no clinical symptoms or cannula losses.

\subsection{The Chemical Compositions and Physical Characteristics of Ingredients}

Wheat bran, $\mathrm{CB}, \mathrm{SH}$ and $\mathrm{RB}$ have a low SDF/IDF ratio, while OB and SBP have a high content of SDF content, SDF/IDF ratio and water binding capacity (Table 2). The RB contains the lowest contents of TDF and NSP compared with the other feed ingredients. In addition, CB and OB have more hemicellulose than WB, SBP, RB and SH, but the contents of ADL in SBP and RB were greater than those in $\mathrm{WB}, \mathrm{CB}, \mathrm{SH}$ and $\mathrm{OB}$.

Table 2. The chemical components of different high-fiber feed ingredients ( $\mathrm{g} / \mathrm{kg}$, DM basis) ${ }^{1}$.

\begin{tabular}{lcccccc}
\hline \multicolumn{1}{c}{ Items $^{2}$} & WB & CB & SBP & OB & SH & RB \\
\hline GE, MJ/kg & 18.82 & 18.80 & 18.66 & 19.93 & 17.74 & 21.68 \\
CP & 193 & 161 & 113 & 227 & 221 & 151 \\
NDF & 372 & 565 & 435 & 421 & 679 & 490 \\
ADF & 107 & 176 & 245 & 95 & 488 & 291 \\
ADL & 22 & 24 & 69 & 33 & 19 & 109 \\
Cellulose & 85 & 152 & 175 & 62 & 469 & 182 \\
Hemicellulose & 264 & 389 & 190 & 326 & 191 & 199 \\
TDF & 480 & 686 & 805 & 494 & 739 & 331 \\
SDF & 50 & 76 & 316 & 194 & 149 & 57 \\
IDF & 430 & 609 & 489 & 299 & 590 & 274 \\
SDF/IDF, \% & 11.6 & 12.5 & 64.6 & 64.9 & 25.3 & 20.8 \\
NSP & 458 & 662 & 735 & 461 & 720 & 223 \\
Starch & 167 & 145 & 76 & 279 & 95 & 291 \\
Water binding capacity, g/g & 5.14 & 5.32 & 9.52 & 7.86 & 5.7 & 3.91 \\
\hline
\end{tabular}

${ }^{1}$ Analyses were conducted in duplicate. ${ }^{2} \mathrm{ADF}=$ acid detergent fiber; $\mathrm{ADL}=$ acid detergent lignin; $\mathrm{CB}=$ corn bran; $\mathrm{CP}=$ crude protein; $\mathrm{DM}=$ dry matter; $\mathrm{EE}=$ ether extract; $\mathrm{IDF}=$ insoluble dietary fiber; $\mathrm{NDF}=$ neutral detergent fiber; $\mathrm{OB}=$ oat bran; $\mathrm{OM}=$ organic matter; $\mathrm{RB}=$ rice bran; $\mathrm{SDF}=$ soluble dietary fiber; $\mathrm{SBP}=$ sugar beet pulp; $\mathrm{SH}=$ soybean hulls; TDF = total dietary fiber; $\mathrm{WB}=$ wheat bran. $\mathrm{OM}$, TDF, cellulose and hemicellulose were calculated with the following equations: $\mathrm{OM}=\mathrm{DM}-$ ash; $\mathrm{TDF}=\mathrm{SDF}+\mathrm{IDF}$; cellulose $=\mathrm{NDF}-\mathrm{ADF}$; hemicellulose = ADF - ADL; non-starch polysaccharide (NSP) $=$ TDF - ADL.

\subsection{The Apparent Ileal Digestibility (AID) of Chemical Components}

The AID of GE and DE content in the OB diet were greater $(P<0.05)$ than for CB, SBP, SH and RB diets (Table 3). Pigs fed WB and OB diets had greater $(P<0.05)$ AID of DM and OM than pigs fed the other dietary treatments. The AID values of ash and EE in the SBP diet were the lowest $(P<0.05)$ 
among all diets. Pigs fed the OB diet had greater $(P<0.05)$ AID of TDF than those fed the WB, CB, SBP, $\mathrm{SH}$ and RB diets. The AID of NDF and hemicellulose in the OB diet were greatest $(P<0.05)$ compared with the other dietary treatments.

Table 3. The AID values of chemical components for pigs fed diets with different high-fiber ingredients ${ }^{1}$.

\begin{tabular}{|c|c|c|c|c|c|c|c|c|}
\hline \multicolumn{9}{|c|}{ Diets } \\
\hline Items, $\%^{2}$ & WB & CB & SBP & OB & $\mathrm{SH}$ & RB & SEM & $P$-Value \\
\hline $\mathrm{DE}, \mathrm{MJ} / \mathrm{kg}$ & $12.52^{b}$ & $12.23^{b c}$ & $12.15^{b c}$ & $12.95^{a}$ & $12.07^{c}$ & $12.09^{c}$ & 0.10 & $<0.01$ \\
\hline GE & $75.43^{a b}$ & $72.04^{b}$ & $72.89^{b}$ & $77.77^{\mathrm{a}}$ & $71.87^{b}$ & $72.84^{b}$ & 1.04 & $<0.01$ \\
\hline $\mathrm{DM}$ & $75.37^{\mathrm{a}}$ & $70.23^{b}$ & $69.35^{b}$ & $74.74^{\mathrm{a}}$ & $68.56^{b}$ & $68.95^{b}$ & 0.88 & $<0.01$ \\
\hline Ash & $14.97^{\mathrm{a}}$ & $18.64^{\mathrm{a}}$ & $2.14^{b}$ & $24.59^{\mathrm{a}}$ & $18.25^{\mathrm{a}}$ & $19.72^{\mathrm{a}}$ & 4.39 & $<0.01$ \\
\hline OM & $78.16^{\mathrm{a}}$ & $72.55^{b}$ & $74.16^{b}$ & $77.94^{\mathrm{a}}$ & $71.13^{b}$ & $73.54^{b}$ & 0.82 & $<0.01$ \\
\hline $\mathrm{EE}$ & $80.85^{a}$ & $86.25^{a}$ & $57.26^{b}$ & $95.12^{a}$ & $94.27^{\mathrm{a}}$ & $94.24^{\mathrm{a}}$ & 5.42 & $<0.01$ \\
\hline TDF & $2.71 \mathrm{bc}$ & $6.55^{b}$ & $6.33^{b}$ & $13.89^{\mathrm{a}}$ & $2.66^{b c}$ & $2.33^{c}$ & 2.07 & 0.02 \\
\hline SDF & $5.33^{c}$ & $9.14^{\mathrm{c}}$ & $12.33^{c}$ & $38.61^{b}$ & $48.93^{\mathrm{a}}$ & $10.00^{c}$ & 3.34 & $<0.01$ \\
\hline IDF & 1.58 & 5.00 & 4.00 & 3.67 & 1.93 & 1.33 & 1.22 & 0.26 \\
\hline NDF & $14.03^{b c}$ & $9.25^{c}$ & $20.40^{b}$ & $32.95^{a}$ & $15.19^{b c}$ & $9.27^{\mathrm{c}}$ & 3.11 & $<0.01$ \\
\hline $\mathrm{ADF}$ & 4.50 & 2.80 & 7.02 & 9.04 & 4.70 & 1.67 & 5.46 & 0.12 \\
\hline Cellulose & 5.47 & 1.82 & 3.70 & 8.62 & 7.02 & 0.70 & 8.83 & 0.39 \\
\hline Hemicellulose & $20.38^{c}$ & $13.15^{\mathrm{c}}$ & $45.48^{b}$ & $62.96^{\mathrm{a}}$ & $45.35^{b}$ & $23.27^{c}$ & 3.45 & $<0.01$ \\
\hline
\end{tabular}

$1 \mathrm{a}, \mathrm{b}, \mathrm{c}$ Least squares means in a row without a common superscript are different $(P<0.05)$. Each treatment included 6 replicates $(n=6) .{ }^{2} \mathrm{ADF}=$ acid detergent fiber; AID = apparent ileal digestibility; $\mathrm{CB}=$ corn bran; DE = digestible energy; $\mathrm{DM}=$ dry matter; $\mathrm{EE}=$ ether extract; $\mathrm{IDF}=$ insoluble dietary fiber; $\mathrm{NDF}=$ neutral detergent fiber; $\mathrm{OB}=\mathrm{oat}$ bran; $\mathrm{OM}=$ organic matter; $\mathrm{RB}=$ rice bran; $\mathrm{SDF}=$ soluble dietary fiber; $\mathrm{SBP}=$ sugar beet pulp; $\mathrm{SH}=$ soybean hulls; $\mathrm{TDF}=$ total dietary fiber; $\mathrm{WB}=$ wheat bran

\subsection{The Apparent Total Tract Digestibility (ATTD) of Chemical Components}

The DE contents and the ATTD of GE and OM in SBP and OB diets were greater $(P<0.05)$ compared with the WB, CB, SH and RB diets (Table 4). Pigs fed WB and RB diets had less $(P<0.05)$ ATTD of ash than pigs fed the CB, SBP, OB and SH diets. The ATTD values of EE in pigs fed the SBP diet were the lowest $(P<0.05)$ among all dietary treatments. Pigs fed SBP, OB and SH diets had greater $(P<0.05)$ ATTDs of TDF, SDF, IDF, NDF, ADF, cellulose and hemicellulose compared with pigs fed $\mathrm{WB}, \mathrm{CB}$ and RB diets.

Table 4. The apparent total tract digestibilities (ATTDs) of chemical components for pigs fed diets with different high-fiber ingredients ${ }^{1}$.

\begin{tabular}{|c|c|c|c|c|c|c|c|c|}
\hline \multicolumn{9}{|c|}{ Diets } \\
\hline Items, $\% 2$ & WB & $\mathrm{CB}$ & SBP & OB & SH & RB & SEM & $P$-Value \\
\hline $\mathrm{DE}, \mathrm{MJ} / \mathrm{kg}$ & $14.11^{b c}$ & $14.01 \mathrm{bc}$ & $15.05^{\mathrm{a}}$ & $14.88^{\mathrm{a}}$ & $14.65^{a b}$ & $13.70^{c}$ & 0.12 & $<0.01$ \\
\hline GE & $85.03^{c}$ & $82.50^{\mathrm{d}}$ & $90.27^{\mathrm{a}}$ & $89.38^{a}$ & $87.14^{b}$ & $82.51^{\mathrm{d}}$ & 0.66 & $<0.01$ \\
\hline $\mathrm{DM}$ & $84.66^{b}$ & $81.59^{c}$ & $89.82^{\mathrm{a}}$ & $88.49^{a}$ & $86.72^{a b}$ & $78.90^{\mathrm{d}}$ & 0.71 & $<0.01$ \\
\hline Ash & $28.28^{b}$ & $43.34^{\mathrm{a}}$ & $41.84^{\mathrm{a}}$ & $41.81^{\mathrm{a}}$ & $51.24^{\mathrm{a}}$ & $26.57^{b}$ & 2.62 & $<0.01$ \\
\hline $\mathrm{OM}$ & $87.27^{b}$ & $83.30^{c}$ & $92.29^{a}$ & $91.47^{\mathrm{a}}$ & $88.53^{b}$ & $83.77^{c}$ & 0.63 & $<0.01$ \\
\hline $\mathrm{EE}$ & $60.65^{a}$ & $57.88^{a}$ & $18.80^{\mathrm{c}}$ & $67.26^{\mathrm{a}}$ & $40.39^{b}$ & $40.47^{b}$ & 3.87 & $<0.01$ \\
\hline TDF & $37.78^{b}$ & $30.31^{\mathrm{b}}$ & $72.54^{\mathrm{a}}$ & $71.87^{a}$ & $72.32^{\mathrm{a}}$ & $39.13^{b}$ & 3.52 & $<0.01$ \\
\hline SDF & $65.75^{b}$ & $68.28^{b}$ & $93.55^{a}$ & $96.31^{\mathrm{a}}$ & $86.38^{a}$ & $43.51^{\mathrm{c}}$ & 5.47 & $<0.01$ \\
\hline IDF & $37.01^{d}$ & $28.68^{\mathrm{de}}$ & $60.80^{a b}$ & $47.72 \mathrm{bc}$ & $69.48^{a}$ & $38.83^{\mathrm{cd}}$ & 4.31 & $<0.01$ \\
\hline NDF & $35.91^{\mathrm{b}}$ & $36.46^{b}$ & $69.59^{a}$ & $76.27^{\mathrm{a}}$ & $68.59^{\mathrm{a}}$ & $32.77^{b}$ & 2.83 & $<0.01$ \\
\hline $\mathrm{ADF}$ & $13.74^{\mathrm{d}}$ & $28.41^{c}$ & $65.17^{a}$ & $54.22^{b}$ & $62.27^{a b}$ & $12.13^{\mathrm{d}}$ & 3.06 & $<0.01$ \\
\hline Cellulose & $14.85^{\mathrm{d}}$ & $32.31^{\mathrm{c}}$ & $62.52^{a}$ & $51.82^{b}$ & $64.76^{a}$ & $31.53^{c}$ & 3.71 & $<0.01$ \\
\hline Hemicellulose & $47.49^{\mathrm{c}}$ & $39.07^{c}$ & $73.62^{b}$ & $85.91^{\mathrm{a}}$ & $76.57^{b}$ & $46.29^{c}$ & 3.17 & $<0.01$ \\
\hline
\end{tabular}




\subsection{The Hindgut Disappearance of Chemical Components}

The disappearance of GE, DE, OM, DM, ADF and cellulose in the hindguts of pigs fed SBP and $\mathrm{SH}$ diets were greater $(P<0.05)$ than in pigs fed the $\mathrm{WB}, \mathrm{CB}, \mathrm{OB}$ and $\mathrm{RB}$ diets (Table 5). The hindgut disappearance of ash was less $(P<0.05)$ for pigs fed the RB diet compared to values for pigs fed the other diets. Pigs fed SBP, OB and SH diets had greater $(P<0.05)$ fermentation of TDF and NDF in the hindgut than pigs fed WB, CB and RB diets. The fermentation of SDF in the hindguts of pigs fed the SBP diet was greatest $(P<0.05)$ among all dietary treatments.

Table 5. The hindgut disappearance of chemical components in pigs fed diets with different high-fiber ingredients ${ }^{1}$.

\begin{tabular}{|c|c|c|c|c|c|c|c|c|}
\hline \multicolumn{9}{|c|}{ Diets } \\
\hline Items, $\%{ }^{2}$ & WB & CB & SBP & ОВ & $\mathrm{SH}$ & RB & SEM & $P$-Value \\
\hline $\mathrm{DE}, \mathrm{MJ} / \mathrm{kg}$ & $1.59^{c}$ & $1.78^{c}$ & $2.90^{\mathrm{a}}$ & $1.93^{b c}$ & $2.58^{a b}$ & $1.61^{\mathrm{c}}$ & 0.02 & $<0.01$ \\
\hline GE & $9.60^{b}$ & $10.46^{\mathrm{b}}$ & $17.38^{a}$ & $11.61^{b}$ & $15.27^{\mathrm{a}}$ & $9.67^{b}$ & 0.22 & $<0.01$ \\
\hline DM & $9.29^{c}$ & $11.36^{b c}$ & $20.47^{\mathrm{a}}$ & $13.75^{b}$ & $18.16^{\mathrm{a}}$ & $9.95^{c}$ & 0.24 & $<0.01$ \\
\hline Ash & $13.31^{\mathrm{cd}}$ & $24.70^{\mathrm{ab}}$ & $39.70^{\mathrm{a}}$ & $17.22^{b}$ & $32.99^{a}$ & $6.85^{\mathrm{d}}$ & 2.20 & $<0.01$ \\
\hline $\mathrm{OM}$ & $9.11^{\mathrm{c}}$ & $10.75^{c}$ & $18.13^{\mathrm{a}}$ & $13.53^{b}$ & $17.40^{\mathrm{a}}$ & $10.23^{c}$ & 0.21 & $<0.01$ \\
\hline $\mathrm{EE}$ & -20.30 & -18.37 & -38.46 & -27.86 & -53.88 & -53.77 & 3.82 & 0.06 \\
\hline TDF & $35.05^{c}$ & $23.76^{d}$ & $66.21^{\mathrm{a}}$ & $57.98^{b}$ & $69.66^{\mathrm{a}}$ & $36.80^{c}$ & 3.25 & $<0.01$ \\
\hline SDF & $30.42^{c}$ & $59.14^{b}$ & $81.22^{\mathrm{a}}$ & $57.70^{b}$ & $37.45^{\mathrm{c}}$ & $33.51^{c}$ & 3.63 & $<0.01$ \\
\hline IDF & $35.43^{b}$ & $23.68^{c}$ & $56.80^{a}$ & $44.05^{b}$ & $67.55^{\mathrm{a}}$ & $37.50^{b}$ & 3.05 & $<0.01$ \\
\hline NDF & $21.88^{c}$ & $27.21^{c}$ & $49.19^{a}$ & $43.27^{b}$ & $53.40^{\mathrm{a}}$ & $23.50^{c}$ & 2.31 & $<0.01$ \\
\hline $\mathrm{ADF}$ & $10.35^{\mathrm{d}}$ & $25.61^{c}$ & $58.15^{a}$ & $45.18^{b}$ & $57.57^{\mathrm{a}}$ & $10.56^{\mathrm{d}}$ & 2.42 & $<0.01$ \\
\hline Cellulose & $9.38^{\mathrm{d}}$ & $30.49^{c}$ & $58.82^{\mathrm{a}}$ & $43.20^{b}$ & $57.74^{\mathrm{a}}$ & $30.83^{c}$ & 2.75 & $<0.01$ \\
\hline Hemicellulose & 27.09 & 25.92 & 28.14 & 22.95 & 31.22 & 23.02 & 2.48 & 0.42 \\
\hline
\end{tabular}

\subsection{Correlations between Fiber Components' Digestibility and Concentrations of VFA in the Ileal Digesta and} Feces

In the samples of ileal digesta (Table 6), the AID of GE was positively correlated with the AID of DM and OM $(P<0.05)$, and the total VFA concentration showed a significant correlation with the AID of cellulose $(P<0.05)$. In the fecal samples, concentration of acetate was positively correlated with the ATTD of IDF $(P<0.05)$ (Table 7$)$. The ATTD of GE was positively correlated $(P<0.05)$ with the ATTD of $\mathrm{DM}, \mathrm{OM}, \mathrm{NDF}, \mathrm{ADF}$, hemicellulose and TDF. There were positive correlations among the ATTD values of different fiber fractions, such as TDF, SDF, IDF, NDF, ADF, cellulose and hemicellulose. Prediction equations for acetate, propionate, butyrate and total VFA concentrations in the feces of pigs fed six dietary treatments were developed (Table 8 ). No suitable predictive equation for fecal propionate concentration was observed using the ATTD of different fiber components $(P>0.10)$. The predictive equation for fecal acetate concentration using a combination of ADF and SDF digestibility $\left(R^{2}=0.85\right.$; $P=0.06)$ is better than those equations using the ATTD of $\operatorname{ADF}\left(R^{2}=0.55 ; P=0.09\right)$ or IDF $\left(R^{2}=0.72\right.$; $P=0.03)$. The predictive equations for fecal butyrate $\left(R^{2}=0.65 ; P=0.05\right)$ and total VFA concentrations $\left(R^{2}=0.61 ; P=0.07\right)$ were developed by using the ATTD of IDF. 
Table 6. Coefficients of correlation among the AIDs of non-fibrous components or ileal fermentation of fiber components and VFA concentration in ileal digesta of pigs ${ }^{1}$.

\begin{tabular}{|c|c|c|c|c|c|c|c|c|c|c|c|c|c|c|c|}
\hline Items $^{2}$ & Acetate & Propionate & Butyrate & $\begin{array}{l}\text { Total } \\
\text { VFA }\end{array}$ & $\begin{array}{c}G E \\
\text { Digestibility }\end{array}$ & $\begin{array}{c}\text { DM } \\
\text { Digestibility }\end{array}$ & $\begin{array}{c}\text { OM } \\
\text { Digestibility }\end{array}$ & $\begin{array}{c}C P \\
\text { Digestibility }\end{array}$ & $\begin{array}{c}\text { TDF } \\
\text { Digestibility }\end{array}$ & $\begin{array}{c}\text { SDF } \\
\text { Digestibility }\end{array}$ & $\begin{array}{c}\text { IDF } \\
\text { Digestibility }\end{array}$ & $\begin{array}{c}\text { NDF } \\
\text { Digestibility }\end{array}$ & $\begin{array}{c}\text { ADF } \\
\text { Digestibility }\end{array}$ & $\begin{array}{l}\text { Cellulose } \\
\text { Digestibility }\end{array}$ & $\begin{array}{c}\text { Hemicellulose } \\
\text { Digestibility }\end{array}$ \\
\hline Acetate & 1 & 0.62 & 0.40 & 0.12 & -0.82 & -0.76 & -0.78 & -0.42 & -0.49 & 0.16 & 0.08 & -0.36 & -0.17 & -0.16 & -0.03 \\
\hline Propionate & & 1 & 0.38 & -0.14 & -0.63 & -0.64 & -0.70 & 0.09 & -0.70 & 0.43 & -0.59 & -0.46 & -0.45 & -0.08 & -0.06 \\
\hline Butyrate & & & 1 & 0.20 & -0.18 & -0.55 & -0.49 & 0.45 & 0.30 & 0.76 & 0.16 & 0.41 & 0.37 & 0.30 & 0.73 \\
\hline Total VFA & & & & 1 & 0.13 & 0.24 & 0.10 & 0.22 & 0.59 & 0.48 & 0.36 & 0.55 & 0.71 & $0.86^{* *}$ & 0.42 \\
\hline GE digestibility & & & & & 1 & $0.89 * *$ & $0.92 * * *$ & 0.29 & 0.68 & 0.14 & -0.02 & 0.77 & 0.67 & 0.63 & 0.48 \\
\hline DM digestibility & & & & & & 1 & $0.94^{* * *}$ & 0.07 & 0.45 & -0.08 & -0.03 & 0.50 & 0.46 & 0.53 & 0.13 \\
\hline OM digestibility & & & & & & & 1 & -0.06 & 0.45 & -0.21 & -0.09 & 0.56 & 0.51 & 0.42 & 0.21 \\
\hline CP digestibility & & & & & & & & 1 & 0.48 & 0.66 & 0.03 & 0.33 & 0.12 & 0.36 & 0.37 \\
\hline TDF digestibility & & & & & & & & & 1 & 0.32 & 0.63 & 0.85 ** & 0.77 & 0.49 & 0.64 \\
\hline SDF digestibility & & & & & & & & & & 1 & -0.07 & 0.52 & 0.47 & 0.75 & $0.75 *$ \\
\hline IDF digestibility & & & & & & & & & & & 1 & 0.26 & 0.34 & -0.05 & 0.10 \\
\hline NDF digestibility & & & & & & & & & & & & 1 & $0.96^{* * *}$ & 0.78 & $0.90^{* *}$ \\
\hline ADF digestibility & & & & & & & & & & & & & 1 & 0.78 & $0.87^{* *}$ \\
\hline $\begin{array}{l}\text { Cellulose } \\
\text { digestibility }\end{array}$ & & & & & & & & & & & & & & 1 & 0.76 \\
\hline $\begin{array}{l}\text { Hemicellulose } \\
\text { digestibility }\end{array}$ & & & & & & & & & & & & & & & 1 \\
\hline
\end{tabular}

$\mathrm{NDF}=$ neutral detergent fiber; $\mathrm{OM}=$ organic matter; $\mathrm{SDF}=$ soluble dietary fiber; $\mathrm{VFA}=$ volatile fatty acid; TDF = total dietary fiber.

Table 7. Coefficients of correlation among the ATTDs of non-fibrous components or intact fermentation of fiber components and VFA concentration in feces of pigs ${ }^{1}$.

\begin{tabular}{|c|c|c|c|c|c|c|c|c|c|c|c|c|c|c|}
\hline Items $^{2}$ & Acetate & Propionate & Butyrate & $\begin{array}{l}\text { Total } \\
\text { VFA } \\
\end{array}$ & $\begin{array}{c}\text { GE } \\
\text { Digestibility }\end{array}$ & $\begin{array}{c}\text { DM } \\
\text { Digestibility }\end{array}$ & $\begin{array}{c}\text { OM } \\
\text { Digestibility }\end{array}$ & $\begin{array}{c}\text { TDF } \\
\text { Digestibility }\end{array}$ & $\begin{array}{c}\text { SDF } \\
\text { Digestibility }\end{array}$ & $\begin{array}{c}\text { IDF } \\
\text { Digestibility }\end{array}$ & $\begin{array}{c}\text { NDF } \\
\text { Digestibility }\end{array}$ & $\begin{array}{c}\text { ADF } \\
\text { Digestibility }\end{array}$ & $\begin{array}{c}\text { Cellulose } \\
\text { Digestibility }\end{array}$ & $\begin{array}{c}\text { Hemicellulose } \\
\text { Digestibility }\end{array}$ \\
\hline Acetate & 1 & $0.94 * * *$ & $0.99 * * *$ & $0.99^{* * *}$ & 0.47 & 0.53 & 0.42 & 0.64 & 0.55 & $0.81^{* *}$ & 0.60 & 0.75 & 0.77 & 0.54 \\
\hline Propionate & & 1 & $0.94 * * *$ & $0.97^{* * *}$ & 0.22 & 0.32 & 0.17 & 0.43 & 0.39 & 0.64 & 0.40 & 0.57 & 0.58 & 0.35 \\
\hline Butyrate & & & 1 & $0.99^{* * *}$ & 0.53 & 0.60 & 0.49 & 0.64 & 0.56 & 0.78 & 0.64 & 0.77 & 0.75 & 0.60 \\
\hline Total VFA & & & & 1 & 0.42 & 0.49 & 0.37 & 0.58 & 0.50 & 0.75 & 0.58 & 0.70 & 0.70 & 0.51 \\
\hline GE digestibility & & & & & 1 & $0.97 * * *$ & $0.99 * * *$ & $0.81^{* *}$ & 0.78 & 0.64 & $0.92 * * *$ & $0.85^{* *}$ & 0.73 & $0.91 * * *$ \\
\hline DM digestibility & & & & & & 1 & $0.96^{* * *}$ & 0.72 & 0.76 & 0.56 & $0.89 * *$ & 0.85 ** & 0.67 & $0.84^{* *}$ \\
\hline OM digestibility & & & & & & & 1 & 0.75 & 0.71 & 0.57 & $0.89 * *$ & 0.79 & 0.66 & $0.88^{* *}$ \\
\hline TDF digestibility & & & & & & & & 1 & $0.90^{* *}$ & $0.93^{* * *}$ & $0.94 * * *$ & $0.93 * * *$ & $0.96^{* * *}$ & $0.92 * * *$ \\
\hline SDF digestibility & & & & & & & & & 1 & 0.78 & $0.92 * * *$ & $0.95^{* * *}$ & 0.90 ** & 0.83 ** \\
\hline IDF digestibility & & & & & & & & & & 1 & 0.80 & $0.87^{* *}$ & $0.97 * * *$ & 0.77 \\
\hline NDF digestibility & & & & & & & & & & & 1 & $0.94 * * *$ & $0.88^{* *}$ & $0.98 * * *$ \\
\hline ADF digestibility & & & & & & & & & & & & 1 & $0.95^{* * *}$ & $0.86^{* *}$ \\
\hline $\begin{array}{l}\text { Cellulose } \\
\text { digestibility }\end{array}$ & & & & & & & & & & & & & 1 & $0.82^{* *}$ \\
\hline $\begin{array}{l}\text { Hemicellulose } \\
\text { digestibility }\end{array}$ & & & & & & & & & & & & & & 1 \\
\hline
\end{tabular}

$1 * *$ Represents $0.05<P<0.01 ; * * *$ represents $P<0.01{ }^{2} \mathrm{ADF}=$ acid detergent fiber; ATTD = apparent total tract digestibility; $\mathrm{DM}=\mathrm{dry}$ matter; IDF $=$ insoluble dietary fiber; NDF $=$ neutral detergent fiber; $\mathrm{OM}=$ organic matter; $\mathrm{SDF}=$ soluble dietary fiber; $\mathrm{VFA}=$ volatile fatty acid; TDF = total dietary fiber. 
Table 8. The prediction equations for fecal VFA concentration by using the ATTDs of different dietary fiber components in pigs ${ }^{1}$.

\begin{tabular}{|c|c|c|c|}
\hline Numbers & Equations & $\mathbf{R}^{2}$ & $P$-Value \\
\hline \multicolumn{4}{|l|}{ Predicted acetate } \\
\hline 1 & Acetate $(\mathrm{mg} / \mathrm{g})=0.0621 \times$ ATTD of ADF $(\%)+5.1927$ & 0.55 & 0.09 \\
\hline 2 & Acetate $(\mathrm{mg} / \mathrm{g})=0.0976 \times$ ATTD of IDF $(\%)+3.2321$ & 0.72 & 0.03 \\
\hline 3 & Acetate $(\mathrm{mg} / \mathrm{g})=0.2078 \times$ ATTD of ADF $(\%)-0.1450 \times$ ATTD of SDF $(\%)+5.1929$ & 0.85 & 0.06 \\
\hline \multicolumn{4}{|l|}{ Predicted butyrate } \\
\hline 1 & Butyrate $(\mathrm{mg} / \mathrm{g})=0.0587 \times$ ATTD of IDF $(\%)-0.4960$ & 0.65 & 0.05 \\
\hline \multicolumn{4}{|l|}{ Predicted total VFA } \\
\hline 1 & Total VFA $(\mathrm{mg} / \mathrm{g})=0.2376 \times$ ATTD of IDF $(\%)+2.5864$ & 0.61 & 0.07 \\
\hline
\end{tabular}

${ }^{1}$ The prediction equation for fecal propionate concentration was not built by using the ATTDs of different fiber components. ADF $=$ acid detergent fiber; ATTD = apparent total tract digestibility; IDF = insoluble dietary fiber; $\mathrm{SDF}=$ soluble dietary fiber; $\mathrm{VFA}=$ volatile fatty acid. 


\section{Discussion}

In the present study, results indicated that the apparent ileal digestibility (AID) of dietary fiber fractions ranged from $0.70 \%$ (the AID of cellulose) to $48.93 \%$ (the AID of SDF). Those results support those reported by Bach Knudsen et al. [18], who found that the apparent ileal digestibility (AID) of NSP, which is the difference between TDF and lignin, in pigs, ranged from $-7 \%$ to $40 \%$. Importantly, some studies have reported that both the gastrointestinal digesta and the feces contain a significant amount of endogenous fibrous components from nondietary materials that interfere with the determination of dietary fiber fermentation $[19,20]$. The fermentation capacity of dietary fiber that is not corrected for the endogenous loss of fiber components can greatly underestimate dietary fiber fermentation. Therefore, there was a limitation to evaluating the fermentation of high-fiber feed ingredients in our study owing to neglecting the endogenous loss of fiber components. The apparent total tract digestibility (ATTD) of SDF in all dietary treatments, except for RB diet, in the present study, was greater than IDF, which supports results of Urriola and Stein [21], indicating an average apparent total tract digestibility (ATTD) of SDF of $20 \%$ units greater than IDF. A small difference in the apparent total tract digestibility (ATTD) of SDF and IDF in the RB diet may be associated with the high degree of polysaccharide polymerization of $\mathrm{RB}$, resulting in depressed SDF digestibility. The high DE content in the ileum, and apparent ileal digestibility (AID) of GE, TDF, NDF and cellulose in the OB diet, were associated with the high contents of SDF and $\beta$-glucan compared with other diets. That indicates that fiber fermentation for the OB diet provided more energy in the small intestine compared with the other dietary treatments. That result is consistent with a previous report indicating that $\beta$-glucan is highly fermentable in the small intestine because of its solubility characteristics compared with those of xylose and arabinose [22]. In spite of a high content of SDF in SBP, the lower apparent ileal digestibility (AID) of GE, SDF, NDF and hemicellulose may result from the high portion of ADL, which is hardly fermented by bacteria in the intestines of pigs [23]. The greatest ileal fermentation of SDF in the SH diet was associated with its physicochemical properties and the high contents of fermentable oligosaccharides and soluble NSP. The greater apparent ileal digestibility (AID) of DM and $\mathrm{OM}$ in the $\mathrm{WB}$ diet resulted from its structure and physical properties, such as bulking, compared with that for $\mathrm{CB}, \mathrm{SBP}, \mathrm{SH}$ and $\mathrm{RB}$ diets.

In the present study, pigs fed the $\mathrm{OB}, \mathrm{SBP}$ and $\mathrm{SH}$ diets had greater apparent total tract digestibility (ATTD) of all fiber fractions compared with values for pigs fed $\mathrm{CB}, \mathrm{WB}$ and RB diets, resulting in a higher DE content in the total digestive tract. The higher fermentable capacity of OB, SBP and SH was mainly associated with higher SDF content, leading to more retention time of fiber fractions in the intestines of pigs. Chabeauti et al. [24] found that the apparent total tract digestibility (ATTD) of NSP in growing pigs varies from $16.3 \%$ for wheat straw, $43.5 \%$ for WB and $69.5 \%$ for SBP to $79.1 \%$ for $\mathrm{SH}$. The poor fiber fermentation of WB is ascribed to its high insoluble fiber content that makes the dietary fiber less fermentable compared with highly fermentable pectin substances in SBP and $\mathrm{SH}$ [25]. The higher apparent total tract digestibility (ATTD) of GE for the pigs fed SBP, OB and SH diets was due to the greater capacity for fermentation of fiber fractions than for $W B, C B$ and $R B$ diets. Those results are consistent with the findings of Urriola and Stein [21], which showed that pigs fed the $30 \%$ SBP or SH diets had greater apparent total tract digestibility (ATTD) of GE and TDF compared with pigs fed a $30 \%$ corn distillers dried grains with soluble (DDGS) diet. Lyu et al. [26] also reported that the apparent total tract digestibility (ATTD) of GE, DM and NDF in the diet with $30 \%$ OB was greater than for a diet with $30 \% \mathrm{WB}$ fed to growing pigs. Pigs fed the SBP and SH diets had greater fermentation of GE, DM, OM, TDF, IDF, NDF, ADF and cellulose in their hindguts than those pigs fed the WB, CB and RB diets. Those results indicated that fermentation of fibrous fractions and the digestibility of non-fibrous components in the gut of pigs were improved due to the existence of more fermentable SDF, resulting from the longer retention time of digesta. The lower fermentation of GE, DM, OM, SDF, ADF and cellulose in the hindguts of pigs fed the OB diet was due to less of the substrates entering into large intestine, resulting from the high fermentation capacity in the foregut of the pig. The greater hindgut disappearance of SDF in the SBP diet may be attributed to more SDF 
fractions of SBP flowing into the hindguts of pigs as substrates because of the low ileal fermentation of fiber. The fermentation of hemicellulose in the hindgut was not different among dietary treatments which indicated that most of the hemicellulose was fermented in the small intestines of pigs. Jaworski and Stein [27] reported that the ileal fermentation of insoluble hemicellulose in some high-fiber diets and ingredients was close to the apparent cecal digestibility of insoluble hemicellulose, indicating that degradation of these fractions is negligible in the cecum. The results showed the apparent total tract digestibility (ATTD) of EE in the feces was lower than the apparent ileal digestibility (AID) of EE in the ileal digesta of pigs. The negative values for the fermentation of EE in the hindgut in the present study are consistent with previous reports $[21,28]$. The negative values are most likely a consequence of microbes in the hindgut using carbohydrates for synthesis of fatty acids, as well as endogenous VFA from non-dietary components.

It is accepted that the concentration of VFA in the ileal digesta and feces of pig accounts for a small proportion of VFA production [29], because most VFA produced by gut bacteria was absorbed. Meanwhile, the endogenous mucin and microbial cells in the pig intestine are rich in IDF fractions, resulting in the production of VFA derived from non-dietary components' fermentation, as well as dietary fiber fermentation [20]. It was also a limitation that the role of VFA produced by fermenting non-dietary components was neglected in our study. In our previous study [11], the high lactate content in the ileal digesta of pigs fed the OB diet is consistent with the current result for more AID of TDF compared to other dietary treatments, which indicates that fiber fermentation of OB primarily produced more lactate in the small intestines of pigs than other fiber fractions from CB, WB, SBP, $\mathrm{SH}$ and RB. Bach Knudsen and Canibe reported high concentrations and flow of lactate in the ilea of cannulated pigs after feeding them a diet supplemented with OB because of its high content of $\beta$-glycan [30]. The concentration of VFA in the feces of pigs fed the SH diet was the greatest compared with all other diets, resulting from its greater content of fermentable oligosaccharides and soluble NSP, similar to results of Freire et al. [31]. Fiber sources affected total VFA concentration in the ileal digesta and feces of pigs in our previous study [11], in which the pigs fed the SBP, OB and SBP had higher VFA concentrations compared to those fed the WB, CB and RB diets. However, it has been reported that there is no difference in total VFA in the ileal digesta of pigs fed diets with WB, SBP, corn DDGS, pea hulls or pea inner fiber [9]. Those inconsistent results for differences in VFA concentration among various feed ingredients were associated with dietary fiber level and pig body weight. Carneiro et al. [32] compared the effects of two fiber sources, WB and maize cobs in pigs and found no differences in the amounts of VFA in the small intestine; however, the pigs fed the maize cobs diet showed the greater proportion of acetate and a lower proportion of butyrate, which accounted for the total VFA in the cecum, compared to those fed the WB diet. Therefore, the variation in fermentability among different dietary fibers is not only associated with the amount of substrate, but also the source of the fiber fraction and its physical characteristics. It is worth mentioning that a high concentration of copper $(100 \mathrm{mg} / \mathrm{kg} \mathrm{vs} .4 \mathrm{mg} / \mathrm{kg})$ was provided to the pigs in the present study to be close to actual swine production in China and maintain a good performance of pigs in comparison to recommendation requirement of NRC (2012). The antimicrobial potentials of copper and zinc have been reported in many previous studies [33,34]. However, a publication indicated the diets with $150 \mathrm{mg} / \mathrm{kg}$ of copper from copper hydroxychloride had no significantly negative effects on the concentrations of VFA in growing pigs, although the activity of gut microbiota may be impaired by a high concentration of copper [35]. Overall, the effects of trace minerals and antibiotic supplementation on fiber fermentation and VFA production should be clarified in further study.

In the present study, concentrations of acetate, propionate, butyrate and total VFA were positively correlated with the apparent total tract digestibility (ATTD) values of insoluble fiber fractions, which agrees with results from numerous studies in which there was a positive relationship between fermentation of insoluble fiber sources and concentration of butyrate in the large intestine [36,37]. The development of prediction equations for fecal VFA concentrations indicated that the digestibility of IDF is the best single variable with which to predict the concentration of VFA in the feces of 
pigs compared to the apparent total tract digestibility (ATTD) of other fiber components. However, the prediction equations for fecal VFA were developed on a basis of six dietary treatments in the present study, which were formulated with six different fiber-rich ingredients. The fermentable capacities of more fiber-rich feeds should be added into the prediction equations for VFA concentration to improve the accuracy and precision of the equations. In addition, some studies found that soluble fractions of dietary fiber are fermented faster and yield greater amounts of VFA than for fermentation of insoluble fractions [6,38]. Those different results indicated that concentration of VFA is not only associated with the chemical composition of fiber, but also their physical characteristics and molecular structure. On the other hand, in spite of the higher fermentable capacity of SDF, the feed ingredients, such as SBP and OB, are rich in SDF, but they are not always used to feed animals owing to their supplies and prices. In contrast, insoluble fibrous feed ingredients are common in the formulations for swine. Therefore, considering the lower fermentable capacity of IDF and the positive relationship between IDF digestibility and VFA concentrations, it is necessary that nutritionists continue to explore ways to improve insoluble fiber fermentation and increase the energy supplied, such as through feed processing technology and enzyme supplementation. It is also crucial to explore the interactions of fiber fermentation between fiber sources and levels in the formulation of pig diets to quantify the requirement of dietary fiber, resulting in the achievement of efficient utilization of fibrous ingredients.

\section{Conclusions}

The fermentable capacity of fiber components derived from various fiber-rich ingredients varies in the different segments of the digestive tracts of pigs owing to their different chemical compositions and physical properties. The high concentrations of VFA in feces of pigs were associated with the fermentation of IDF. Those differences in the fermentable capacity of fiber among different fibrous ingredients provide a reference for the use of various high-fiber ingredients in formulated diets for pigs, in accordance with the positive correlation between VFA concentration and IDF digestibility. The ways to improve IDF fermentation should be considered to increase the energy supplied and the prebiotic effects of VFA for pigs, improving the sustainability of the swine production.

Supplementary Materials: The following are available online at http://www.mdpi.com/2076-2615/10/2/263/s1, Table S1: The dietary formulation in the recovery period of pigs after surgery in the present study.

Author Contributions: Formal analysis, J.Z.; data curation, Y.B.; resources, G.Z.; writing-original draft preparation, J.Z.; writing — review and editing, L.L.; supervision, C.L.; funding acquisition, C.L. All authors have read and agreed to the published version of the manuscript.

Funding: This research was funded by National Key R\&D Program of China, grant number 2018YFD0500405 and the 111 Project, grant number B16044.

Acknowledgments: We thank Ministry of Agriculture and Rural Affairs Feed Industry Centre for kindly helping lab analysis in this study.

Conflicts of Interest: The authors declare no conflict of interest.

\section{References}

1. Williams, B.A.; Verstegen, M.W.A.; Tamminga, S. Fermentation in the large intestine of single-stomached animals and its relationship to animal health. Nutr. Res. Rev. 2001, 14, 207-227. [CrossRef]

2. Koh, A.; De Vadder, F.; Kovatcheva-Datchary, P.; Backhed, F. From dietary fiber to host physiology: Short-chain fatty acids as key bacterial metabolites. Cell 2016, 165, 1332-1345. [CrossRef] [PubMed]

3. Liu, H.; Wang, J.; He, T.; Becker, S.; Zhang, G.; Li, D.F.; Ma, X. Butyrate: A double-edged sword for health? Adv. Nutr. 2018, 9, 21-29. [CrossRef] [PubMed]

4. Daien, C.I.; Pinget, G.V.; Tan, J.K.; Macia, L. Detrimental impact of microbiota-accessible carbohydrate-deprived diet on gut and immune homeostasis: An overview. Front. Immunol. 2017, 8, 548. [CrossRef] [PubMed] 
5. Chambers, E.S.; Viardot, A.; Psichas, A.; Morrison, D.J.; Murphy, K.G.; Zac-Varghese, S.E.; MacDougall, K.; Preston, T.; Tedford, C.; Finlayson, G.S.; et al. Effects of targeted delivery of propionate to the human colon on appetite regulation, body weight maintenance and adiposity in overweight adults. Gut 2015, 64, 1744-1754. [CrossRef]

6. Jha, R.; Berrocoso, J.D. Review: Dietary fiber utilization and its effects on physiological functions and gut health of swine. Animal 2015, 9, 1441-1452. [CrossRef]

7. Zhao, J.; Liu, P.; Wu, Y.; Guo, P.; Liu, L.; Ma, N.; Levesque, C.; Chen, Y.; Zhang, J.; Ma, X. Dietary fiber increases butyrate-producing bacteria and improves the growth performance of weaned piglets. J. Agric. Food Chem. 2018, 66, 7995-8004. [CrossRef]

8. Davidson, M.H.; McDonald, A. Fiber: Forms and functions. Nutr. Res. 1988, 18, 617-624. [CrossRef]

9. Jha, R.; Leterme, P. Feed ingredients differing in fermentable fibre and indigestible protein content affect fermentation metabolites and faecal nitrogen excretion in growing pigs. Animal 2012, 6, 603-612. [CrossRef]

10. Lærke, H.N.; Arent, S.; Dalsgaard, S.; Bach Knudsen, K.E. Effect of xylanases on ileal viscosity, intestinal fiber modification, and apparent ileal fiber and nutrient digestibility of rye and wheat in growing pigs. J. Anim. Sci. 2015, 93, 4323-4335. [CrossRef]

11. Zhao, J.; Bai, Y.; Tao, S.; Zhang, G.; Wang, J.; Liu, L.; Zhang, S. Fiber-rich foods affects gut bacterial community and short-chain fatty acids production in pig model. J. Funct. Foods 2019, 57, 266-274. [CrossRef]

12. Stein, H.H.; Shipley, C.F.; Easter, R.A. Technical note: A technique for inserting a T-cannula into the distal ileum of pregnant sows. J. Anim. Sci. 1998, 76, 1433-1436. [CrossRef] [PubMed]

13. NRC. Nutrient Requirements of Swine, 11th rev. ed.; National Academies Press: Washington, DC, USA, 2012.

14. AOAC International. Official Methods of Analysis of AOAC International, 18th ed.; Rev. 2.; Hortwitz, W., Latimer, G.W., Jr., Eds.; AOAC Int.: Gaithersburg, MD, USA, 2007.

15. Van Soest, P.J.; Robertson, J.B.; Lewis, B.A. Methods for dietary fiber, neutral detergent fiber, and non-starch polysaccharides in relation to animal nutrition. J. Dairy Sci. 1991, 74, 3583-3597. [CrossRef]

16. Robertson, J.A.; De Monredon, F.D.; Dysseler, P.; Guillon, F.; Amado, R.; Thibault, J. Hydration properties of dietary fibre and resistant starch: A European collaborative study. Lebensm Wiss Technol. 2000, 33, 72-79. [CrossRef]

17. Pan, L.; Ma, X.K.; Wang, H.L.; Xu, X.; Zeng, Z.K.; Tian, Q.Y.; Zhao, P.F.; Zhang, S.; Yang, Z.Y.; Piao, X.S. Enzymatic feather meal as an alternative animal protein source in diets for nursery pigs. Anim. Feed Sci. Technol. 2016, 212, 112-121. [CrossRef]

18. Bach Knudsen, K.E.; Lærke, H.N.; Jørgensen, H. Carbohydrates and Carbohydrate Utilization in Swine. In Sustainable Swine Nutrition; Chiba, L.I., Ed.; John Wiley \& Sons: Ames City, IA, USA, 2013; pp. 109-135.

19. Montoya, C.A.; Henare, S.J.; Rutherfurd, S.M.; Moughan, P.J. Potential misinterpretation of the nutritional value of dietary fiber: Correcting fiber digestibility values for nondietary gut-interfering material. Nutr. Rev. 2016, 74, 517-533. [CrossRef]

20. Montoya, C.A.; Rutherfurd, S.M.; Moughan, P.J. Ileal digesta nondietary substrates from cannulated pigs are major contributors to in vitro human hindgut short-chain fatty acid production. J. Nutr. 2017, 147, 264-271. [CrossRef]

21. Urriola, P.E.; Stein, H.H. Effects of distillers dried grains with solubles on amino acid, energy, and fiber digestibility and on hindgut fermentation of dietary fiber in a corn-soybean meal diet fed to growing pigs. J. Anim. Sci. 2010, 88, 1454-1462. [CrossRef]

22. Jha, R.; Rossnagel, B.; Pieper, R.; Van Kessel, A.; Leterme, P. Barley and oat cultivars with diverse carbohydrate composition alter ileal and total tract nutrient digestibility and fermentation metabolites in weaned piglets. Animal 2010, 4, 724-731. [CrossRef]

23. Glitso, L.V.; Brunsgaard, G.; Hojsgaard, S.; Sandstrom, B.; Bach Knudsen, K.E. Intestinal degradation in pigs of rye dietary fibre with different structural characteristics. Br. J. Nutr. 1998, 80, 457-468. [CrossRef]

24. Chabeauti, E.; Noblet, J.; Carre, B. Digestion of plant cell walls from four different sources in growing pigs. Anim. Feed Sci. Technol. 1991, 32, 207-213. [CrossRef]

25. Karr-Lilienthal, L.K.; Kadzere, C.T.; Grieshop, C.M.; Fahey, G.C., Jr. Chemical and nutritional properties of soybean carbohydrates as related to nonruminants: A review. Livest. Prod. Sci. 2005, 97, 1-12. [CrossRef]

26. Lyu, Z.Q.; Huang, B.; Li, Z.C.; Wang, Z.Y.; Chen, Y.F.; Zhang, S.; Lai, C.H. Net energy of oat bran, wheat bran, palm kernel expellers fed to growing pigs using indirect calorimetry. Anim. Sci. J. 2019, 90, 98-107. [CrossRef] [PubMed] 
27. Jaworski, N.W.; Stein, H.H. Disappearance of nutrients and energy in the stomach and small intestine, cecum, and colon of pigs fed corn-soybean meal diets containing distillers dried grains with solubles, wheat middlings, or soybean hulls. J. Anim. Sci. 2017, 95, 727-739. [CrossRef]

28. Kil, D.Y.; Sauber, T.E.; Jones, D.B.; Stein, H.H. Effect of the form of dietary fat and the concentration of dietary NDF on ileal and total tract endogenous losses and apparent and true digestibility of fat by growing pigs. J. Anim. Sci. 2010, 88, 2959-2967. [CrossRef]

29. Montoya, C.A.; Rutherfurd, S.M.; Moughan, P.J. Kiwifruit fibre level influences the predicted production and absorption of SCFA in the hindgut of growing pigs using a combined in vivo-in vitro digestion methodology. Br. J. Nutr. 2016, 115, 1317-1324. [CrossRef]

30. Bach Knudsen, K.E.; Canibe, N. Breakdown of plant carbohydrates in the digestive tract of pigs fed on wheator oat-based rolls. J. Sci. Food Agric. 2000, 80, 1253-1261. [CrossRef]

31. Freire, J.P.B.; Guerreiro, A.J.G.; Cunha, L.F.; Aumaitre, A. Effect of dietary fibre source on total tract digestibility, caecum volatile fatty acids and digestive transit time in the weaned piglet. Anim. Feed Sci. Technol. 2000, 87, 71-83. [CrossRef]

32. Carneiro, M.S.C.; Lordelo, M.M.; Cunha, L.F.; Freire, J.P.B. Effects of dietary fibre source and enzyme supplementation on faecal apparent digestibility, short chain fatty acid production and activity of bacterial enzymes in the gut of piglets. Anim. Feed Sci. Technol. 2008, 146, 124-136. [CrossRef]

33. Espinosa, C.D.; Fry, R.S.; Usry, J.L.; Stein, H.H. Copper hydroxychloride improves growth performance and reduces diarrhea frequency of weanling pigs fed a corn-soybean meal diet but does not change apparent total tract digestibility of energy and acid hydrolyzed ether extract. J. Anim. Sci. 2017, 95, 5447-5454. [CrossRef] [PubMed]

34. Fry, R.S.; Ashwell, M.S.; Lloyd, K.E.; O’Nan, A.T.; Flowers, W.L.; Stewart, K.R.; Spears, J.W. Amount and source of dietary copper affects small intestine morphology, duodenal lipid peroxidation, hepatic oxidative stress, and mRNA expression of hepatic copper regulatory proteins in weanling pigs. J. Anim. Sci. 2012, 90, 3112-3119. [CrossRef] [PubMed]

35. Espinosa, C.D. Copper from Copper Hydroxychloride in Diets for Growing Pigs Increases Feed Efficiency, Improves Energy Utilization and Changes Intestinal Microbial Activity. Ph.D. Thesis, University of Illinois, Urbana, IL, USA, 2019.

36. Bhandari, S.K.; Xu, B.; Nyachoti, C.M.; Giesting, D.W.; Krause, D.O. Evaluation of alternatives to antibiotics using an Escherichia coli ${\mathrm{K} 88^{+}}$model of piglet diarrhea: Effect on gut microbial ecology. J. Anim. Sci. 2008, 86, 836-847. [CrossRef] [PubMed]

37. Molist, F.; Ywazaki, M.; Gómez de Segura, A.; Hermes, R.G.; Gasa, J.; Pérez, J.F. Administration of loperamide and addition of wheat bran to the diets of weaner pigs decrease the incidence of diarrhoea and enhance their gut maturation. Br. J. Nutr. 2010, 103, 879-885. [CrossRef] [PubMed]

38. Urriola, P.E.; Shurson, G.C.; Stein, H.H. The digestibility of dietary fiber in distillers co-products fed to growing pigs. J. Anim. Sci. 2010, 88, 2373-2381. [CrossRef]

(C) 2020 by the authors. Licensee MDPI, Basel, Switzerland. This article is an open access article distributed under the terms and conditions of the Creative Commons Attribution (CC BY) license (http://creativecommons.org/licenses/by/4.0/). 